\title{
Influence of Nitrogen Metabolism on Lipid Accumulation by Rhodosporidium toruloides CBS 14
}

\author{
By CHRISTOPHER T. EVANS $†$ AND COLIN RATLEDGE* \\ Department of Biochemistry, University of Hull, Hull HU6 7RX,UK
}

(Received 14 November 1983)

\begin{abstract}
Rhodosporidium toruloides CBS 14 was grown in batch culture with urea as principal nitrogen source. The lipid content increased from $18 \%(\mathrm{w} / \mathrm{w})$ with $\mathrm{NH}_{4}^{+}$-grown cells to $52 \%(\mathrm{w} / \mathrm{w})$ after $90 \mathrm{~h}$ growth. Urea was rapidly taken up and catabolized to release intracellular $\mathrm{NH}_{4}^{+}$, which accumulated between 10 and $30 \mathrm{~h}$ growth. The increase in pool $\mathrm{NH}_{4}^{+}$content was mirrored by an increase in citric acid accumulation and excretion from the cells. The production of intracellular $\mathrm{NH}_{4}^{+}$, sufficient to permit lipid accumulation, could be attributed to the increase in activity of urease over this period. Similarly, other catabolic enzymes, such as arginase, threonine dehydratase and $\mathrm{NAD}^{+}$: glutamate dehydrogenase, were also induced (or derepressed) when the respective amino acids were used as medium nitrogen source. Growth with mixed organic and inorganic nitrogen compounds considerably decreased the lipid content and was accompanied by a reduction in activity of the various catabolic enzymes concerned. The significance of nitrogen catabolism during lipid accumulation in this yeast is discussed.
\end{abstract}

\section{INTRODUCTION}

In the preceding paper we examined the effect of the medium nitrogen source on lipid accumulation in oleaginous yeasts (Evans \& Ratledge, 1984), it having been reported that certain yeasts accumulated more lipid when an organic- rather than an inorganic-nitrogen source was used (Steiner, 1959; Blinc \& Hočevar, 1953; Witter et al., 1974). We were able to substantiate such claims with Rhodosporidium toruloides and Trichosporon cutaneum and subsequently studied the former yeast to explain how such yeasts were able to increase their lipid contents from less than $20 \%$ of the biomass to over $50 \%$. We concluded that the influence of the nitrogen source on lipid accumulation was essentially a batch effect in that it could not be demonstrated in continuous culture. The phenomenon was thus probably attributable to the transient appearance of certain key catabolites of the nitrogen compound used, influencing the production of citrate, and thereby acetyl-CoA (Evans \& Ratledge, 1984).

In an attempt to extend the generality of these findings made with glutamate as nitrogen source, we have examined the growth and lipid accumulation by Rs. toruloides CBS 14 in batch culture using urea as the principal nitrogen source. We also report the use of mixed nitrogen sources for growth, which enabled us to characterize further the relation between nitrogen catabolism and lipid accumulation in this yeast.

\section{METHODS}

Yeast and growth. Rhodosporidium toruloides CBS 14, which was used throughout this study, was grown at $30^{\circ} \mathrm{C}$ in either 1-litre vortex-aerated vessels or $250 \mathrm{ml}$ shake flasks on culture medium, as previously described (Evans \& Ratledge, 1984) using glucose at $30 \mathrm{~g} \mathrm{l}^{-1}$ and each nitrogen source (sterilized by membrane filtration) at $0 \cdot 13 \mathrm{~g} \mathrm{~N}^{-1}$.

$\dagger$ Present address: Department of Cellular and Molecular Biology, University of Michigan, Ann Arbor, Michigan 48109, USA.

Abbreviations: GDH, glutamate dehydrogenase; GOGAT, glutamate synthase. 
Analyses. Cell dry weights, lipid contents of biomass, and $\mathrm{NH}_{4}^{+}$and citrate concentrations were determined by methods given previously (Evans \& Ratledge, 1984). Urea was assayed by the method of Gutmann \& Bergmeyer (1974). Assays for $\mathrm{NAD}^{+}$: glutamate dehydrogenase (EC 1.4.1.2), $\mathrm{NADP}^{+}$: glutamate dehydrogenase (EC 1.4.1.4), glutamate synthase (EC 1.4.1.13) and glutamine synthetase (EC 6.3.1.2) were by the methods listed previously (Evans \& Ratledge, 1984). Threonine dehydratase (EC 4.2.1.16) was assayed by the method of Shizuta \& Tokushige (1971), urease (EC 3.5.1.5) by the procedure of Roon \& Levenberg (1970) and arginase (EC 3.5.3.1) by the method of Schimke (1970).

Preparation of intracellular extracts and cell extracts. These were by the procedures given previously (Evans \& Ratledge, 1984).

\section{RESULTS}

Growth and lipid production by Rs. toruloides using urea as nitrogen source

We previously reported that a correlation existed between the degree of lipid accumulation by Rs. toruloides and the intracellular concentrations of $\mathrm{NH}_{4}^{+}, 2$-oxoglutarate and citrate when glutamate was used as sole nitrogen source (Evans \& Ratledge, 1984). In order to test the hypothesis that catabolism of the organic nitrogen source stimulated lipid production by some mechanism, we monitored the changes in metabolite concentrations during a batch culture using urea as sole nitrogen source (Fig. $1 a$ ).

Uptake of urea from the medium was markedly faster than that of $\mathrm{NH}_{4}^{+}$or glutamate, and intracellular $\mathrm{NH}_{4}^{+}$could be detected after $10 \mathrm{~h}$ growth. The concentration of $\mathrm{NH}_{4}^{+}$increased to give a peak between 25 and $30 \mathrm{~h}$, then declined rapidly. Between $10 \mathrm{~h}$ and $30 \mathrm{~h}$ growth, the ratio of urea uptake to intracellular $\mathrm{NH}_{4}^{+}$production was approximately $46: 1$. The intracellular citrate concentration also increased sevenfold between 10 and $40 \mathrm{~h}$, with a concomitant increase in cellular lipid content. The lipid content continued to rise at about $0.14 \mathrm{~g} \mathrm{lipid} \mathrm{h}^{-1}$ until about $60 \mathrm{~h}$, then showed very little increase, reaching a final value of $52 \%$ of the cell dry weight after $90 \mathrm{~h}$ growth.

As with the glutamate-grown cells (cf. Evans \& Ratledge, 1984), considerable citric acid excretion occurred between 25 and $40 \mathrm{~h}$ growth, correlating with the rise in intracellular citrate and $\mathrm{NH}_{4}^{+}$concentrations a few hours earlier (Fig. $1 b$ ). More significant was the increase in cellular urease activity observed in urea-grown cells (Fig. 2); presumably this activity was the source of all intracellular $\mathrm{NH}_{4}^{+}$detected during 20 to $30 \mathrm{~h}$ growth. (The inoculum for the ureacontaining culture medium had been grown on $\mathrm{NH}_{4}^{+}$as nitrogen source.) Although activity of urease was present in $\mathrm{NH}_{4} \mathrm{Cl}$-grown cells, it was ninefold higher in the urea-grown cells and gradually fell to the basal level of activity after $50 \mathrm{~h}$, coinciding with the disappearance of urea from the medium (compare Fig. $1 a$ with Fig. 2).

\section{Effect of different nitrogen sources on various enzymes of nitrogen metabolism in}

\section{Rs. toruloides CBS 14}

The findings with both glutamate- and urea-grown cultures therefore indicate that some aspect of nitrogen catabolism is responsible for increased lipid synthesis. To confirm these findings we examined the activities of various enzymes of nitrogen metabolism in cells growth with other nitrogen compounds (Table 1). As with growth on glutamate and urea, the activities of the first enzymes in the catabolic sequence of arginine (arginase) and threonine (threonine dehydratase) metabolism were ninefold and fourfold higher, respectively, than in $\mathrm{NH}_{4}^{+}$-grown cells. The activity of threonine dehydratase was considerably higher on other amino acids such as aspartate, alanine and glutamate, indicating that it could well be repressed by growth on $\mathrm{NH}_{4}^{+}$.

The lowest activity of threonine dehydratase was recorded on urea. Similarly the activities or arginase and $\mathrm{NAD}^{+}$:glutamate dehydrogenase $\left(\mathrm{NAD}^{+}: \mathrm{GDH}\right)$ were lower in $\mathrm{NH}_{4}^{+}$-grown cells than in their respective amino acid cultures.

Activity of an NADPH-specific glutamate synthase (GOGAT) or equivalent enzyme system could be detected in most extracts of $R s$. toruloides. [Although GOGAT has not previously been conclusively detected in or isolated from yeasts or fungi (Brown, 1980), we consider that the observed activity is probably that of GOGAT and was not due to a combined glutaminase and $\mathrm{NADP}^{+}: \mathrm{GDH}$ activity, as the former enzyme has a very high $K_{\mathrm{m}}$ for $\mathrm{NH}_{4}^{+}$.] 


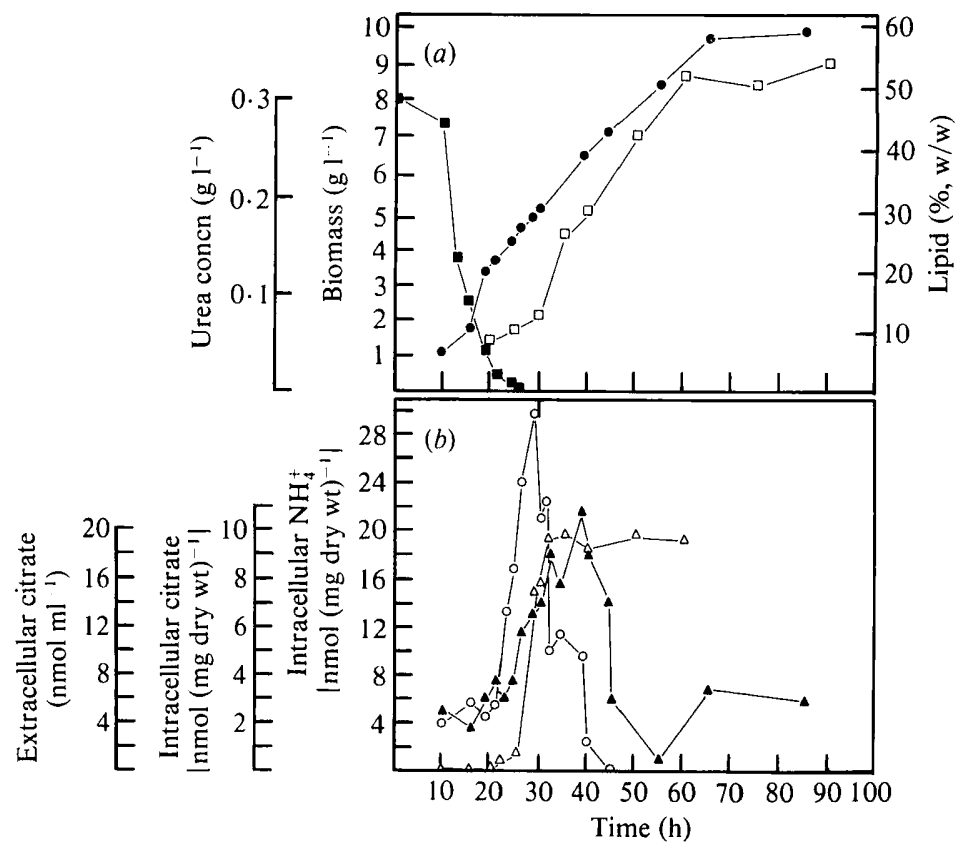

Fig. 1. Growth and lipid production by $R$ s. toruloides grown in batch culture with urea as sole nitrogen source. (a) - Biomass; $\square$, extracellular urea; $\square$, lipid, percentage of biomass (the rate of glucose consumption was similar to that given previously for glutamate-grown cultures of the same organism; Evans \& Ratledge, 1984). (b) $\boldsymbol{\Delta}$, Intracellular citrate; $\triangle$, extracellular citrate; $\bigcirc$, intracellular $\mathrm{NH}_{4}^{+}$.

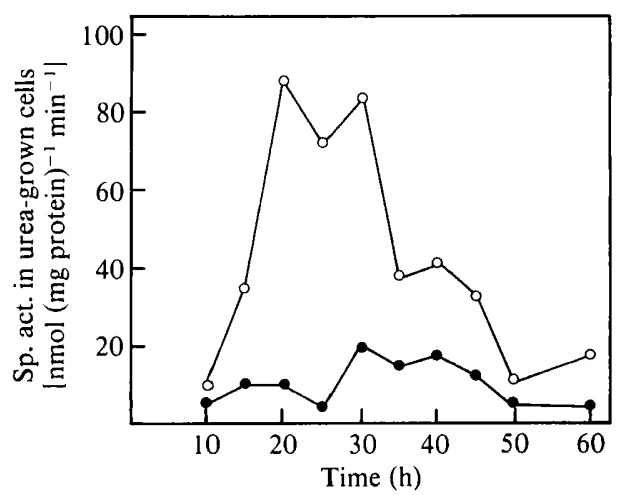

Fig. 2. Activity of urease in Rs. toruloides during batch culture: $\bigcirc$, urea-grown cells;, $\mathrm{NH}_{4}^{+}$-grown cells.

Effect of growth on mixed nitrogen sources on lipid production and activities of various enzymes of nitrogen metabolism in Rs. toruloides CBS 14

Table 2 shows the effect of mixing organic and inorganic nitrogen sources on lipid accumulation in $R s$. toruloides. The glutamate $/ \mathrm{NH}_{4} \mathrm{Cl}$ mixture resulted in a lipid content lower than that expected for a 1:1 mixture of these compounds. A more pronounced effect was seen with the urea/ $/ \mathrm{NH}_{4} \mathrm{Cl}$ mixture, where the lipid content was reduced from $52 \%$ to $22 \%$, which is almost as low as that obtained with $\mathrm{NH}_{4} \mathrm{Cl}$ alone. Proline $/ \mathrm{NH}_{4} \mathrm{Cl}$ and arginine $/ \mathrm{NH}_{4} \mathrm{Cl}$ mixtures produced similar decreases in lipid content, whereas asparagine $/ \mathrm{NH}_{4} \mathrm{Cl}$ and threonine $/ \mathrm{NH}_{4} \mathrm{Cl}$ produced little change. The glutamate/urea mixture showed only a decrease in lipid production from $52-39 \%(\mathrm{w} / \mathrm{w})$, whereas the glutamate/asparagine combination resulted in a more substantial decrease. 
Table 1. Activities of various enzymes of nitrogen metabolism in Rs. toruloides grown on different nitrogen sources

Cultures were grown in $250 \mathrm{ml}$ shake flasks and extracts were prepared from cells after $30 \mathrm{~h}$ growth. Enzyme activities are expressed as nmol substrate converted (mg protein) ${ }^{-1} \mathrm{~min}^{-1}$.

\begin{tabular}{|c|c|c|c|c|c|c|c|c|c|}
\hline \multirow[b]{2}{*}{$\begin{array}{l}\text { Nitrogen } \\
\text { source }\end{array}$} & \multirow[b]{2}{*}{$\begin{array}{c}\text { Lipid } \\
(\%, w / w)\end{array}$} & \multicolumn{2}{|c|}{$\begin{array}{c}\text { Glutamate } \\
\text { dehydrogenase }\end{array}$} & \multirow[b]{2}{*}{$\begin{array}{l}\text { Glutamine } \\
\text { synthetase }\end{array}$} & \multicolumn{2}{|c|}{$\begin{array}{l}\text { Glutamate } \\
\text { synthase }\end{array}$} & \multirow[b]{2}{*}{$\begin{array}{l}\text { Threonine } \\
\text { dehydratase }\end{array}$} & \multirow[b]{2}{*}{ Arginase } & \multirow[b]{2}{*}{ Urease } \\
\hline & & $\mathrm{NAD}^{+}$ & $\mathrm{NADP}^{+}$ & & $\mathrm{NAD}^{+}$ & $\mathrm{NADP}^{+}$ & & & \\
\hline $\mathrm{NH}_{4} \mathrm{Cl}$ & 18 & 28 & 295 & 14 & 0 & 17 & 34 & 12 & 21 \\
\hline $\mathrm{NaNO}_{3}$ & 21 & 40 & 310 & 6 & 1 & 19 & ND & ND & ND \\
\hline Glycine & 38 & 40 & 211 & 9 & 0 & 12 & ND & ND & ND \\
\hline Alanine & 42 & 229 & 170 & 18 & 1 & 9 & 117 & ND & ND \\
\hline Glutamine & 43 & 30 & 120 & 5 & 1 & 10 & ND & ND & ND \\
\hline Threonine & 46 & 37 & 140 & 12 & 2 & 14 & 135 & ND & 25 \\
\hline Aspartate & 46 & 257 & 91 & 20 & 2 & 19 & 129 & ND & ND \\
\hline Asparagine & 46 & 49 & 173 & 14 & 0 & 8 & ND & ND & ND \\
\hline Urea & 52 & 29 & 397 & 21 & 2 & 10 & 12 & ND & 94 \\
\hline Glutamate & 52 & 209 & 95 & 12 & 3 & 11 & 107 & 65 & 44 \\
\hline Arginine & 54 & 24 & 165 & 9 & 0 & 12 & ND & 104 & 89 \\
\hline
\end{tabular}

ND, Not determined.

Table 2. Effect of growth on mixed nitrogen sources on lipid production and activities of enzymes of nitrogen metabolism

Cultures were grown in $500 \mathrm{ml}$ shake flasks at $30^{\circ} \mathrm{C}$. Enzyme activities are expressed as nmol substrate converted (mg protein $)^{-1} \mathrm{~min}^{-1}$. All nitrogen sources were in a $1: 1(\mathrm{~mol} \mathrm{~N} / \mathrm{mol} \mathrm{N})$ ratio.

\begin{tabular}{|c|c|c|c|c|c|c|}
\hline \multirow[b]{2}{*}{ Nitrogen source } & \multirow[b]{2}{*}{$\begin{array}{c}\text { Lipid* } \\
(\%, w / w)\end{array}$} & \multicolumn{2}{|c|}{ Glutamate dehydrogenase } & \multirow[b]{2}{*}{$\begin{array}{l}\text { Threonine } \\
\text { dehydratase }\end{array}$} & \multirow[b]{2}{*}{ Arginase } & \multirow[b]{2}{*}{ Urease } \\
\hline & & $\mathrm{NAD}^{+}$ & $\mathrm{NADP}^{+}$ & & & \\
\hline Glutamate $+\mathrm{NH}_{4} \mathrm{Cl}$ & $28(52)$ & 69 & 185 & 52 & 29 & 29 \\
\hline Glutamate + Urea & $39(52)$ & 140 & 207 & ND & ND & 42 \\
\hline Glutamate + Asparagine & $33(52)$ & 109 & 119 & ND & ND & ND \\
\hline Urea $+\mathrm{NH}_{4} \mathrm{Cl}$ & $22(52)$ & 40 & 300 & ND & ND & 31 \\
\hline Threonine $+\mathrm{NH}_{4} \mathrm{Cl}$ & $37(46)$ & ND & ND & 119 & ND & ND \\
\hline Proline $+\mathrm{NH}_{4} \mathrm{Cl}$ & $25(49)$ & ND & ND & ND & ND & ND \\
\hline Asparagine $+\mathrm{NH}_{4} \mathrm{Cl}$ & $40(46)$ & 46 & 218 & ND & ND & ND \\
\hline Arginine $+\mathrm{NH}_{4} \mathrm{Cl}$ & $30(54)$ & 32 & 194 & ND & 29 & 20 \\
\hline
\end{tabular}

ND, Not determined.

* The figures in parentheses refer to the lipid content of the cells when grown in the presence of only the first nitrogen source of the mixture (see Table 1).

These observations may be partly explained by the effects of these mixtures on the activity of the various catabolic enzymes. The activity of $\mathrm{NAD}^{+}: \mathrm{GDH}$ was fivefold lower than on glutamate alone, again indicating that synthesis may be repressed by the presence of $\mathrm{NH}_{4}^{+}$ions. The activity of $\mathrm{NADP}^{+}: \mathrm{GDH}$ was relatively unaffected by any of the mixtures. The activity of threonine dehydratase was still high even in the threonine $/ \mathrm{NH}_{4} \mathrm{Cl}$ mixture, which indicated that its synthesis was not subject to $\mathrm{NH}_{4}^{+}$repression but was likely to be induced by the presence of threonine. Both arginase and urease exhibited low activities in all the mixtures examined, showing that both were likely to be controlled by $\mathrm{NH}_{4}^{+}$repression. These results, however, do not account for any effects of the extracellular $\mathrm{NH}_{4}^{+}$concentration on the amino acid uptake systems in Rs. toruloides, which could also affect lipid accumulation, as discussed later.

\section{DISCUSSION}

The results reported here confirm the hypothesis proposed in the preceding paper (Evans \& Ratledge, 1984) that the rate of lipid production is influenced by the products of catabolism of the medium nitrogen source, rather than being the result of direct stimulation by the nitrogen 
(a) Growth with $\mathrm{NH}_{4} \mathrm{Cl}$

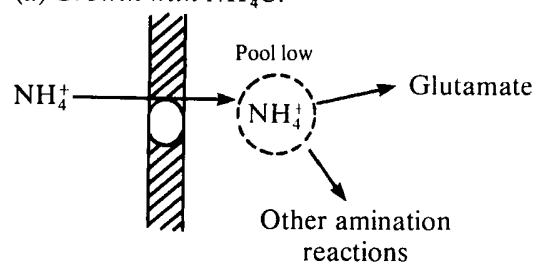

(b) Growth with amino acid
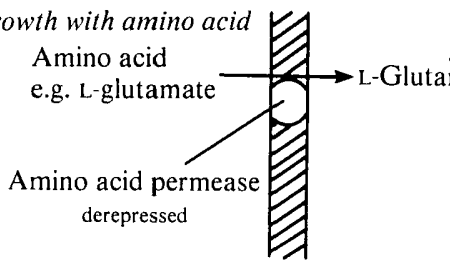

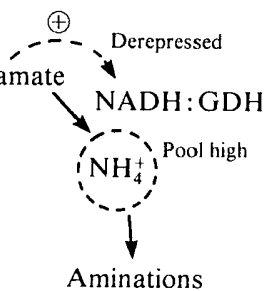

(c) Growth with mixed sources

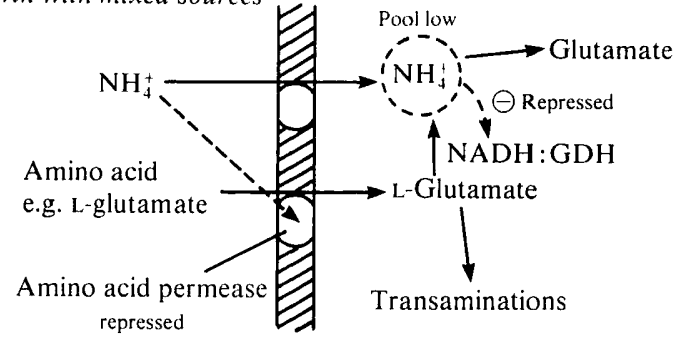

Fig. 3. Possible mechanisms of uptake and metabolism of nitrogen sources in Rs. toruloides CBS 14 .

compound itself. This is therefore a general phenomenon in Rs. toruloides. The results indicate that the concentration of intracellular $\mathrm{NH}_{4}^{+}$is probably of considerable regulatory significance during the initial stages of lipid biosynthesis.

The increase in the pool $\mathrm{NH}_{4}^{+}$concentration prior to accumulation of citrate and lipid suggests that $\mathrm{NH}_{4}^{+}$may have to accumulate to a significant concentration in the cell before being able to influence metabolism sufficiently to promote lipid production. The results indicate that the pool $\mathrm{NH}_{4}^{+}$content is generated due to induction (or derepression) of the first enzymes of the various catabolic sequences, e.g. activity of the first enzyme of urea breakdown, urease, increased in the early stages of growth resulting in an elevated $\mathrm{NH}_{4}^{+}$pool.

$\mathrm{NH}_{4}^{+}$could conceivably be the key regulatory metabolite in the explanation of how various other organic nitrogen compounds affect lipid production. Other compounds from which $\mathrm{NH}_{4}^{+}$ can be released during assimilation, e.g. arginine, allantoin, glutamine, threonine and ornithine (Middelhoven \& Hoogkamer-Te Niet, 1981), all resulted in high lipid contents. Presumably the variation in lipid contents observed with the various organic sources (between 30 and $52 \%$ ) is due to the extent of $\mathrm{NH}_{4}^{+}$release and accumulation during metabolism: urea releases $\mathrm{NH}_{4}^{+}$ directly; arginine produces urea and ornithine, both of which are catabolized to $\mathrm{NH}_{4}^{+}$; allantoin is converted to $\mathrm{NH}_{4}^{+}$via urea by allantoinase; asparagine releases $\mathrm{NH}_{4}^{+}$directly; proline is degraded by proline oxidase, and threonine by threonine dehydratase (see Eddy, 1980; Pateman \& Kinghorn, 1976; Bender, 1975 for general reviews).

The activities of the first enzymes of the various catabolic sequences (e.g. arginase, threonine dehydratase, urease) were all usually higher in the respective amino acid-grown cells than in $\mathrm{NH}_{4}^{+}$-grown cells. The importance of the initial catabolism was illustrated by the growth in cultures containing mixed nitrogen sources. Addition of $\mathrm{NH}_{4}^{+}$to the culture media containing glutamate, proline, urea and arginine resulted in a marked decrease in lipid content and in a repression of the catabolic $\mathrm{NAD}^{+}$: glutamate dehydrogenase, urease and arginase. Repression of these enzymes by $\mathrm{NH}_{4}^{+}$is not uncommon in yeast (cf. Middelhoven \& Hoogkamer-Te Niet, 1981). Neither threonine dehydratase nor asparaginase was subject to repression by $\mathrm{NH}_{4}^{+}$and likewise the lipid contents of these cells did not decrease significantly.

The decrease in lipid contents with mixed nitrogen sources may not be wholly attributable to the repression of the various catabolic sequences. The presence of extracellular $\mathrm{NH}_{4}^{+}$can severely retard transport of various amino acids into yeast cells (Eddy, 1980) and this is itself would lower the rate of intracellular $\mathrm{NH}_{4}^{+}$formation (see Fig. 3). In yeast, the general amino acid permease, and various specific transport processes, are repressed in the presence of $\mathrm{NH}_{4}^{+}$ 
and rapidly derepressed when extracellular $\mathrm{NH}_{4}^{+}$is depleted (Eddy, 1980, 1982; Roon et al., 1975). Thus the dramatic decreases in lipid contents and probably due to the dual effect of $\mathrm{NH}_{4}^{+}$ simultaneously repressing both transport and the catabolic systems for dissimilation of the amino acids.

Transport of $\mathrm{NH}_{4}^{+}$ions themselves into cells of $\mathrm{Rs}$. toruloides must also be tightly coupled to their assimilation to prevent any significant accumulation taking place when $\mathrm{NH}_{4}^{+}$is used as sole nitrogen source. Accumulation and regulatory significance of intracellular $\mathrm{NH}_{4}^{+}$has also been reported in other systems (Habison et al., 1979; Rohr \& Kubicek, 1981). The latter workers showed that citric acid producing Aspergillus spp. could accumulate very high $\mathrm{NH}_{4}^{+}$ concentrations (between 25 and $15 \mathrm{mM}$ ) throughout growth. It is conceivable that only certain yeasts, such as Rhodosporidium and Trichosporon spp. (see Evans \& Ratledge, 1983), are able to accumulate and tolerate intracellular $\mathrm{NH}_{4}^{+}$concentrations to any significant extent. Fundamental differences in nitrogen metabolism between different species of oleaginous yeasts may therefore account for the ability of various organic nitrogen compounds to stimulate lipid accumulation. The mechanisms by which the products of nitrogen metabolism can regulate lipid production will be reported in subsequent papers.

This work was supported by a Co-operative Award in Science and Engineering from the Science and Engineering Research Council in co-operation with Cadbury-Schweppes plc.

\section{REFERENCES}

Bender, D. A. (1975). Amino Acid Metabolism. London: John Wiley.

Blinc, M. \& Hočevar, B. (1953). Fettanreicherung in Rhodotorula gracilis. Monatshefte für Chemie 84, 1127-1131.

Brown, C. M. (1980). Ammonia assimilation and utilization in bacteria and fungi. In Microorganisms and Nitrogen Sources, pp. 511-535. Edited by J. W. Payne. London: John Wiley.

Brown, C. M., MacDonald-Brown, D. S. \& Meers, J. L. (1974). Physiological aspects of microbial inorganic nitrogen metabolism. Advances in Microbial Physiology 11, 1-52.

EDDY, A. A. (1980). Some aspects of amino acid transport in yeast. In Microorganisms and Nitrogen Sources, pp. 35-62. Edited by J. W. Payne. London: John Wiley.

EDDY, A. A. (1982). Mechanisms of solute transport in selected eukaryotic micro-organisms. Advances in Microbial Physiology 23, 1-78.

Evans, C. T. \& Ratledge, C. (1984). Effect of nitrogen source on lipid accumulation in oleaginous yeasts. Journal of General Microbiology 130, 16931704.

Gutmann, I. \& Bergmeyer, H. U. (1974). Urea. In Methods of Enzymatic Analysis Vol. 4, pp. 17911802. Edited by H. U. Bergmeyer. New York: Academic Press.

Habison, A., Kubicek, C. P. \& Rohr, M. (1979). Phosphofructokinase as a regulatory enzyme in citric acid-producing Aspergillus niger. FEMS Microbiology Letters 5, 39-42.

Middelhoven, W. J. \& Hoogkamer-Te Niet, M. C. (1981). Repression of catabolic NAD-specific gluta- mate dehydrogenase of Saccharomyces cerevisiae by arginase, allantoin and urea. FEMS Microbiology Letters 10, 307-311.

Pateman, J. A. \& Kinghorn, J. R. (1976). Nitrogen metabolism. In The Filamentous Fungi Vol. 2, Biosynthesis and Metabolism, pp. 159-237. Edited by J. E. Smith \& D. R. Berry. London: Edward Arnold.

RoHR, M. \& KUBICEK, C. P. (1981). Regulatory aspects of citric acid fermentation by Aspergillus niger. Process Biochemistry 16, 34-37 (+44).

Roon, R. J. \& LevenberG, B. (1970). $\mathrm{CO}_{2}$ fixation and the involvement of allophanate in the biotinenzyme-catalyzed cleavage of urea. Journal of Biological Chemistry 245, 4593-4595.

RoON, R. J., LARIMORE, F. \& LeVy, J. S. (1975). Inhibition of amino acid transport by ammonium ion in Saccharomyces cerevisiae. Journal of Bacteriology 124, 325-331.

Schimke, R. T. (1979). Arginase (rat liver). Methods in Enzymology 17A, 313-316.

Shizuta, Y. \& Tokushige, M. (1971). Threonine deaminase (degradation) (Escherichia coli). Methods in Enzymology 17B, 575-580.

STEINER, M. (1959). The utilization of amino and amide nitrogen by Endomycopsis vernalis and other yeasts (with special reference to metabolic reactions at the surface of the cells). Symposia of the Society for Experimental Biology 13, 177-192.

Witter, B., Debuch, H. \& Steiner, M. (1974). Die Lipide von Endomycopsis vernalis bei verschiedener Stickstoff-Ernährung. Archives of Microbiology 101, 321-335. 